\title{
A CHEGADA DOS FRANCISCANOS AO JAPÃO E O INÍCIO DA QUERELA MISSIOLÓGICA
}

\author{
Renata Cabral Bernabé \\ Giuseppe Marino ${ }^{2}$
}

Resumo: Este estudo introduz um manuscrito inédito de autoria desconhecida, procedente do arquivo da Real Academia de História de Madri, acerca da querela que surgiu no Japão entre os missionários das diferentes ordens, ao fim do século XVI e início do XVII. Trata-se do princípio da disputa sobre a primazia da evangelização pretendida pelos jesuítas em terras nipônicas a qual se chocou com a firme intenção dos franciscanos em professar a religião cristã naquela missão. Em que pese à bula papal que conferia à Companhia de Jesus o monopólio da evangelização no arquipélago, os frades descalços decidiram seguir com a empreitada. Este ensaio analisa as primeiras acusações franciscanas que deram origem a uma literatura de defesa por parte dos jesuítas cujas respostas não tardaram em chegar.

Palavras-chave: Franciscanos; Jesuítas; Disputas; Memorial; Século cristão japonês.

Abstract: This study introduces an unreleased manuscript, whose authorship is unknown, and is placed in the Royal Academy of History in Madrid, about the quarrel that developed between the missionaries of different orders in the Japanese mission, in the late $16^{\text {th }}$ and early $17^{\text {th }}$ centuries. It deals with the beginning of the disputes about the primacy of the evangelization claimed by the Jesuits in the Land of the Rising Sun which clashed with the firm intention of the Franciscans in order to profess the Christian religion there. Despite the Papal Bull that conferred the Society of Jesus the monopoly over the mission in the archipelago, the discalced friars decided to continue the enterprise. This essay analyses the first Franciscans accusations that gave rise to a defense literature by the Jesuits. The results were no long in coming.

Keywords: Franciscans; Jesuits; Disputes; Memorial; Japanese Christian Century.

1 Doutoranda bolsista Fapesp pelo programa de História Social da Faculdade de Filosofia, Letras e Ciências Humanas da Universidade de São Paulo (FFLCH-USP); recabral31@gmail.com.

2 Doutor pela Universidade Autônoma de Madrid, atualmente professor contratado da Universidade de Fudan; g.marino1982@gmail.com. 


\section{Introdução}

Este artigo tem como função falar da origem da disputa que se engendrou no Japão entre as ordens religiosas, mais especificamente jesuítas e franciscanos. Essa investigação nasce com o propósito de apontar dados novos e ajudar na criação de uma cronologia dos fatos que levaram a tal disputa, aportando-se nos manuscritos de ambas as partes. Não são muitos os historiadores que, ao longo dos anos, jogaram luz sobre as motivações que estão na base desta contenda. Esse ensaio busca, portanto, traçar as causas que levaram à produção da chamada literatura apologética levada a cabo pelos jesuítas (GAY, 1966:9).

Fica patente, ao estudar tal tema, que os franciscanos persistiram nas suas acusações aos jesuítas ao longo dos anos, tendo-se iniciado a contenda antes mesmo da sua chegada. Os argumentos centrais presentes em seus memoriais e outras obras são sinônimo de uma persistência, assim como da intenção que possuíam de seguir com sua forma de cristianizar os chamados povos pagãos. Para além de um hipotético Odium Theologicum entre as ordens (BOXER, 1967:154; ELISON, 1973:80), haviam também interesses temporais que envolviam as coroas ibéricas, os quais não se pode ignorar.

A dificuldade em abordar este tema, no entanto, se dá na desigualdade do número de fontes que temos atualmente disponíveis. Se do lado jesuíta a quantidade é massiva, não se pode dizer o mesmo das outras ordens. Contudo, a partir dos documentos jesuítas é possível de se retirar uma série de dados acerca da querela com os mendicantes, uma vez que neles estão presentes textos e opiniões franciscanas e dominicanas a serem refutadas, como é o exemplo do manuscrito que transcrevemos e colocamos como apêndice deste artigo.

\section{Chegada dos franciscanos no Japão e o início da querela}

Em 1576, os franciscanos iniciaram sua missão nas Filipinas (TRONU, 2015), sob o comando da Coroa espanhola, cujos representantes haviam se instalado no arquipélago desde 1565 (CORREIA, 2008). A missão japonesa era bastante conhecida de todos os missionários europeus graças às diversas edições publicadas na Europa das cartas dos jesuítas que para lá foram ${ }^{3}$. Esta, contudo, se iniciara e se mantivera, até então, sob o comando do padroado pertencente à coroa portuguesa que, por sua vez, havia confiado a missão à Companhia de Jesus. Mesmo após 1580, quando se deu a união das coroas com Felipe II de Espanha, a situação não mudou, ao menos oficialmente, graças às decisões tomadas nas Cortes de Tomar que, em 1581, estipularam que a união era pessoal e que, portanto, os impérios e colônias deveriam se manter administrativamente separados (MANZANO, 2014).

3 Juan Pobre, em sua obra acerca da perda do galeão San Felipe, afirma que as primeiras notícias que chegaram a Castela acerca da conversão que ocorria no Japão pelos jesuítas datava de 1577. In: PEREZ, Lorenzo. Fray Juan Pobre de Zamora: su relación sobre la pérdida del galeón "San Felipe", y martirio de San Pedro Bautista y compañeros. Madri: R. Velasco, 1931. 
Os primeiros religiosos pertencentes ao patronato espanhol a pisar no arquipélago nipônico o fizeram em 1584, devido a um desvio que um navio português que ia de Cavite a Macau teve de fazer em direção a Hirado, por causa do mau tempo (MANZANO, 2104). Neste navio se encontravam três religiosos: um frade franciscano, Frei Juan Pobre (1550-1615), e dois agostinianos. Estes foram bem recebidos, ficaram lá por cerca de dois meses, e voltaram às Filipinas com uma carta do daimyô de Hirado, endereçada ao governador das Filipinas e a Felipe II, se mostrando disposto a fazer comércio com os espanhóis ${ }^{4}$. O encontro, no entanto, não gerou muitos frutos, uma vez que somente em 1592 os espanhóis voltaram a negociar diretamente no arquipélago nipônico (BOXER, 1967).

Os jesuítas, no entanto, desaprovavam a vinda de outras ordens ao Japão e isso foi deixado claro inclusive pelo Visitador Alexandre Valignano (1539-1606) já na sua primeira visita (1579-1582) . Em 1585, mesmo ano em que a embaixada japonesa que o Visitador havia preparado ${ }^{6}$ (CORREIA, 2006) chegou a Roma, o Papa Gregório XIII assinou um breve, Ex pastoralis Officio, o qual conferia à Companhia de Jesus o monopólio da missão japonesa. Ficava, assim, proibida a entrada no Japão de missionários de quaisquer outras ordens.

O rei espanhol, que àquela altura era também monarca do trono português ${ }^{7}$, não desaprovou o breve e inclusive enviou uma carta, em abril de 1586, ao vice-rei da Índia, Dom Duarte de Menezes, e ao capitão maior da China, Diego Montero, na qual reafirmava a proibição de outras ordens de entrar no Japão ${ }^{8}$.

4 A carta se encontra em: A.G.I., Fil., Leg. 34, N. 63, ff. 642r-645v. Traslado de carta del rey de Firando. Hirado, 17 de setembro de 1584 .

5 Valignano escreve sobre a necessidade de não se deixar outras ordens entrarem no Japão tanto na sua obra "Sumário de Japón" (1583) - capítulo: Como no conviene ir a Japón otras Religiones -, quanto nas Resoluções das Consultas que promoveu no Japão quando da sua primeira visita (segunda pergunta das consultas). Ver: VALIGNANO, Alessandro. Sumario de las Cosas de Japón. Editor: Jorge C. Alvarez-Taladriz, Monumenta Nipponica Monographs, Tóquio: Sophia University, v. 9, 1954. Há ainda diversas cartas que são enviadas a Roma defendendo tal posição.

6 Em 1582, Valignano enviou do Japão uma embaixada com cinco jovens, parentes dos senhores japoneses, a Roma. A embaixada chegou a seu destino em 1585.

7 Felipe II de Espanha (1527-1598), que após 1580, com a chamada União Ibérica (1580-1640), passou a ser ao mesmo tempo Felipe I de Portugal.

8 Cedula del rey don Phelipe II por carta suya de Abril de 1586 para que no entren en Japón otros Religiosos que los de la Compañia de Jesús, in Jap. Sin. 27, folio 8-8v. A carta segue parcialmente transcrita: "Don Duarte de Meneses del consejo de Estado de su Majestad y Virrey de la India et a vos Diego Montero que ahora ides por Capitán Mayor de la China y viaxe del Japón y a todos los que adelante fueron, sabed que [...] su Majestad información del grande fruto que hacen los padres de la Compañía en Japón así en la conversión de los gentiles como en la enseñanza de los cristianos y sabiendo que los otros padres están ya en grande número y han hecho diversas casas y colegios y seminarios con más de 200 iglesias en diferentes reinos de Japón deseando que la conversión de Japón pase adelante y que los otros padres sean ayudados y de ninguna manera impedidos del grande 
Aos religiosos mendicantes, no entanto, não agradou a proibição da sua entrada no Japão. O breve foi tema de discussões fervorosas entre jesuítas e franciscanos na década seguinte, mas já em 1587 podemos encontrar referências ao descontentamento dos mendicantes pelo fato de não lhes ser permitida a entrada na China e Japão ${ }^{9}$. Os franciscanos sublinhavam que para um país tão povoado como o Japão eram necessários muitos predicadores e a Companhia de Jesus não teria como dispor de tantos obreiros.

Em julho deste mesmo ano, o general japonês Toyotomi Hideyoshi ${ }^{10}$ (15371598), que até então vinha tendo uma atitude de tolerância para com os cristãos e padres, publicou um édito de expulsão dos missionários jesuítas e proibiu a pregação do cristianismo. Apesar destes terem conseguido permanecer no Japão, a missão passava, a partir de então, ao status de clandestina (BERNABÉ, 2013). O édito de 1587 foi algo muito usado pelos frades como prova da necessidade da ida de outras ordens para

servicio que hacen a nuestro señor y temiendo que por ser una cristiandad nueva y tan apartada y ser ellos gente de costumbres y calidades tan diferentes y contrarias a nuestros modos y costumbres de Europa y que una de las causas por que se mueven los japoneses ha hacerse cristianos ya entiendes que sus leyes son falsas e ver la uniformidad de la doctrina y modo de proceder de los otros padres y por lo contrario la diferencia que hay de leyes entre sus bonzos y así mismo teniendo respeto a irse haciendo de nuevo aquella cristiandad y la gentilidad ser tan libre y poco acostumbrada a los preceptos divinos y humanos y ser por necesaria mucha prudencia y experiencia muy grande recato en publicar nuestra sagrada doctrina y obligarlos a los preceptos positivos de la santa Iglesia y asimismo a ser necesarias a uniformidad de las opiniones y decisiones de los casos en la publicación de diversos preceptos y en las dispensaciones que se han de conceder o negar para que nuestra ley no les parezca demasiadamente pesada ni haya diversidad en el modo de proceder en las otras cosa; y porque sería lo contrario la primera causa de grande impedimento para la conversión de los gentiles y causará gran división, desordenes, escándalos y cisma en aquella nueva cristiandad y habiendo su Majestad tratado con su santidad del modo que en esto se debía guardar para remedio de lo otro y para que no haya semejantes desordenes que impidan el fruto que se hace, determino por consejo de su santidad que no fuesen por ahora clérigos seglares a Japón ni religiosos de otras religiones para que se gobernase aquella cristiandad solo por los padres de la Compañía que abrieron la puerta a la conversión de Japón para que siendo guiada por ellos se guarde esta uniformidad en todo tan necesaria para aquella nueva Iglesia y no [sean] diversos hábitos, diverso modo de proceder y diversas opiniones [...] [f. 8v] 12 de abril de 1586."

9 Fr. Francisco Manrique e Fr. Martín Ignacio de Loyola escreveram acerca disso em uma carta em que enviaram ao rei em 1587. Na carta os frades diziam: "Ningún portugués ni capitán nos osa llevar, y nos han notificado una provisión del virrey de la India que dice que Vuestra Majestad tiene por bien que no entren allí, en la China ni en el Japón, si no fueran los padres de la Compañía; y persuaden los dichos padres que es en perjuicio de la Cristiandad entrar allá nadie; y presentaron un breve que ninguno vaya a Japón, ni aún obispo a hacer su oficio ni los demás a predicar, y con no tener el breve las partes necesarias para ejecutarse, le ejecutan; y tenemos nosotros otros breves de mayor autoridad y no los quieren ver ni entender, todo por no nos tragar por ser castellanos”. Ignacio de Loyola al Rey de 6 de julho de 1587. Cf. SOLA, Emilio, Historia de un Desencuentro, España y Japón 1580-1614, Archivo de la Frontera: e-libros, 2012.

10 Toyotomi Hideyoshi, comandante militar japonês que terminou a unificação do Japão após a morte de Oda Nobunaga (1534-1582). 
auxílio da missão nipônica. Contudo, nenhum movimento de fato foi feito em direção ao Japão, por parte dos franciscanos ou espanhóis, até que em 1592 surgiu uma ótima oportunidade: a chegada, em Manila, de uma embaixada japonesa comandada por um homem chamado Harada ${ }^{11}$ Magoshiro (BOXER, 1967) que dizia portar uma carta de Hideyoshi endereçada ao governador das Filipinas. Do Japão, o Visitador jesuíta - que se encontrava na sua segunda visita à missão nipônica - enviara uma missiva ao reitor da Companhia de Jesus em Manila. Nela, afirmava que um mercador cristão de Meaco ${ }^{12}$ havia dado a entender ao general que seria fácil fazer com que as Filipinas prestassem obediência a ele e o convenceu a mandar tal embaixada. Valignano havia pedido para que o reitor falasse com Gomes Pérez Dasmariñas (1539-1593), governador das Filipinas, e recomendasse que ele não recebesse a embaixada com a desculpa de que não tinha certeza da autenticidade da mesma ${ }^{13}$.

A embaixada, no entanto, não só foi recebida como respondida. Primeiramente Dasmariñas recebeu a carta que Harada trazia consigo. Contudo, uma vez que vinha escrita em caracteres chineses, ele pediu secretamente para Juan Cobo ${ }^{14}$ (ARNAIZ, 1939) fazer a tradução e logo em seguida para o próprio Harada fazê-lo também. As duas traduções resultaram completamente diferentes, sendo que segundo Cobo, Hideyoshi exigia vassalagem por parte do governador das Filipinas, enquanto que para Harada o general só procurava amizade e correspondência com a Espanha. De qualquer maneira, o que Dasmariñas fez foi mandar uma embaixada em resposta a Hideyoshi, encabeçada por $\mathrm{Cobo}^{15}$, na qual dizia querer se certificar se a comitiva de Harada realmente falava em seu nome e, se esse fosse o caso, que ele gostaria de ter amizade com o mesmo. A resposta desta primeira embaixada das Filipinas, no entanto, jamais chegou de volta às mãos dos espanhóis. Isso porque Juan Cobo morreu no caminho de volta, num naufrágio próximo à ilha Formosa, tendo-se perdido, portanto, seu depoimento e os papéis que levava consigo ${ }^{16}$. Dasmariñas então resolveu montar uma

11 Nos documentos ele aparece como Faranda.

12 Miyako, que significa capital. Forma como os jesuítas se referiam a Quioto, capital do Japão naquele período.

13 Alexandre Valignano, carta, 6 de fevereiro de 1592. In: A.R.S.I., Jap. Sin. 31, f. 36v. Traslado de la carta que el padre visitador Alejandro Valignano escribió al rector de Manila. De Nagasaki.

14 Dominicano espanhol que se encontrava nas Filipinas desde 1588 e se dedicara ao estudo do chinês desde então.

15 Cobo pediu para que Juan de Solís, um espanhol que morava há alguns anos no Japão, o acompanhasse como intérprete.

16 Supomos que Hideyoshi recebera bem a embaixada, devido aos acontecimentos que se seguem. Harada descreve como foram bem acolhidos e o provincial dos franciscanos nas Filipinas, Juan de Garrovillas, escreve em sua relação acerca da chegada das duas embaixadas. Ver: Juan de Garrovillas, Relacion y certificacion de las cosas y estados del Japon, por el Provincial de los Descalzos Franciscos y el Cabildo de Manila, 29 de abril de 1595. In: PEREZ, Lorenzo, Cartas y Relaciones del Japon, Madrid: G. López del Horno, 1916. 
segunda embaixada, que partiu no ano seguinte, 1593, mas dessa vez quem a encabeçou foi Pedro Batista, um franciscano. Junto foram outros três franciscanos: Bartolomeu Ruiz (1525-1600), Francisco de San Miguel (1545-1597) e Gonçalo Garcia (?-1597). Após a audiência com Hideyoshi, os quatro franciscanos receberam do governante um local na capital, onde puderam se instalar.

Para os fatos que seguiram a partir daqui há sempre duas versões: a dos franciscanos espanhóis e a dos jesuítas sob o comando da Coroa portuguesa. O que se pode dizer, com absoluta certeza, é que antes disso já havia uma virtual disputa entre a Companhia de Jesus e as ordens mendicantes, posto que os primeiros defendiam sua exclusividade na missão japonesa e os últimos criticavam duramente tal monopólio. A partir da entrada desses quatro franciscanos ${ }^{17}$ iniciouse uma verdadeira guerra de acusações entre as duas ordens, caracterizada pela produção de relações, tratados e apologias, que foram enviadas à Europa (tanto à Santa Sé em Roma quanto à Corte de Felipe II) tendo circulado entre os religiosos de missões nas mais diversas partes do mundo.

As primeiras críticas aos jesuítas do Japão escritas pelos membros ordem de São Francisco são, provavelmente, as que Juan Garrovillas, provincial dos Descalços nas Filipinas, apontou em um memorial que hoje se encontra perdido, mas que o documento aqui transcrito faz referência. Entre os pontos defendidos, os franciscanos acusavam os padres de: tratar mais de mercadoria que de conversão; que os quatro embaixadores que foram a Roma eram "mecánicos o mercaderes"; que a Companhia usurpava a jurisdição do Rei espanhol; que despovoavam terras ao compelirem os gentios a deixarem suas antigas cerimônias; que convertiam cristãos à força e que os padres confessavam por intérpretes ${ }^{18}$. Seguido a isso, o

17 Após a entrada do grupo da embaixada de Pedro Batista, em 1593, foram enviadas outras comitivas de franciscanos a partir das Filipinas sendo que as duas seguintes foram: em 1594, Augustin Rodriguez, Jerônimo de Jesus e Marcelo de Ribadeneira e, em 1596, Martín de la Ascención e Francisco Blanco. Cf. CORREIA, Pedro Lage Reis. A Concepção de Missionação na Apologia de Valignano, Lisboa: Centro Científico e Cultural de Macau, 2008.

18 Há uma outra relação que Gil de la Mata respondeu que se intitula Sumario de una relación que el Provincial de San Francisco envió de las Filipinas en la cual porque se tocan algunas cosas en descrédito de los padres de la Compañia que andan en el Japón, responde a ellas el procurador de aquella provincia. Real Academia de la Historia (R.A.H.), seção "Cortes”, 565, ff. 179-181v. A última folha está em 193. Segue uma transcrição resumida das acusações: 1. “[...] los otros [os franciscanos] fueron recibidos de Cambacodono con mucho contento y que les dio sitio y tienen hecha casa e iglesia y hospital y celebran y predican en público"; 2. "Para prueba de lo que dice el Provincial de San Francisco en su petición presentó ocho testigo [...]"; 3. "[...] un embajador llamado Faranda y que este trató con el Gobernador de aquellas Islas que enviase a Japón algunos religiosos [...]”; 4. “[...] que Cambaco había dicho algunas veces alabándolos dichos frailes que aquellos le contentaban mucho porque menospreciaban el oro y la plata [...]; 5. "Dicen más los dichos testigos que Cambacodono por intercesión de los dichos religiosos se habían reconciliado con los padres de las Compañía [...]” e 6. "Dicen últimamente que hay en el Japón tan gran multitud de cristianos que no bastan para ello los padres de la Compañía [...]". 
procurador dos jesuítas, Gil de la Mata, se viu obrigado a contestar os Capitulos que se dieron al Rey Católico contra la Compañía de la India y Japón el marzo de 95 (MARINO, 2014).

Em janeiro do ano seguinte, o dominicano Bartolomeu Lopez entregou ao papa mais um memorial acusatório ${ }^{19}$. Para além dos pontos supracitados, os jesuítas tiveram que contestar: a facilidade que tinham os frades ao entrar na China e converter os locais; que os padres tratavam da seda com os mercadores; que tinham duas fortalezas "muy artelladas y una fragata"; que os jesuítas eram soberbos e que iam com fausto, em particular quando iam visitar os reis; que não deixaram o bispo de Japão ir ao arquipélago; que não queriam que outros religiosos fossem lá para que não vissem o que faziam; que não predicavam a lei de Deus, seus mandamentos e sacramentos; que repudiavam os frades e não guardavam o impedimento disparitatis cultus ${ }^{20} \mathrm{e}$, por último, que a doutrina da Companhia não era segura.

Há também uma segunda parte deste mesmo memorial ${ }^{21}$, no qual são levantadas as seguintes acusações: que a despeito do que diziam os jesuítas, a embaixada de Juan Cobo fora recebida com muita cortesia por Hideyoshi; que os padres teriam ajudado a um rei cristão com gente e artilharia; que teriam muitas terras, portos, lugares, bens, barcos e artilharia, ganhavam muito dinheiro e andavam muito bem acompanhados e, por fim, que os padres se rebelariam contra Hideyoshi caso ele não expulsasse os frades.

O franciscano Martín de la Ascención também escreveu suas críticas à Companhia $^{22}$. Sua obra ficou famosa depois que o Visitador jesuíta a copiou e a respondeu em sua Apologia (VALIGNANO, 1598). Os principais pontos que Martín se refere em seu tratado são: que o breve Ex pastoralis Officio era inválido; que era contra o monopólio jesuíta e que havia necessidade de que outras ordens fossem ao Japão; que o breve se deu em prejuízo dos reis de Castela; que os padres do Japão ensinavam mal a doutrina, batizando sem examinar, e que a ida dos frades foi muito proveitosa para a missão japonesa (TALADRIZ, 1973).

19 Respuestas a las cosas de más importancia que contiene el Memorial del P. F. Bartholomé López dado a S.S. en enero de 1596 contra la Compañía de Japón, China e India. R.A.H., "Cortes", 565, ff. 194-196v.

20 Proibição da Igreja Católica de que os crentes se casassem com não batizados.

21 Segunda parte del sumario sacado de la relación que el Provincial de San Francisco envió de las Filipinas, a que también responde el Procurador de Japón. R.A.H., "Cortes”, 565, ff. 198r-200v.

22 Breve sumario de dos tratados descritos a mano llenos de falsedades y calumnias que hizo fray Martín de la Ascensión, vizcaíno de nación, y uno de los seis religiosos de San Francisco descalzos que el rey de Japón mandó matar el año de 1597. Archivum Romanum Societatis Iesu (ARSI), Jap sin 27, f. $62-63 \mathrm{v}$. 


\section{Introdução ao documento}

O documento em questão, Resposta da Companhia aos capitulos que se deram a Sua Majestade contra os padres de Japão, é um manuscrito inédito que se encontra no Arquivo da Real Academia da História ${ }^{23}$ de Madri, na coleção Cortes ${ }^{24}$. Nesta seção há dois exemplares deste manuscrito, sendo que o segundo seria uma cópia feita inteiramente pela mão do jesuíta espanhol Antonio Colaço (1568-1647). Essas são as únicas informações bibliográficas que conseguimos recolher a respeito do manuscrito.

Das informações presentes no conteúdo do manuscrito, por sua vez, podemos supor que é uma apologia feita por um jesuíta ${ }^{25}$, provavelmente português - já que está escrito neste idioma, ainda que a obra esteja endereçada a Felipe II de Espanha - respondendo a alguns capítulos que se produziram contra os jesuítas do Japão. Podemos situar esse memorial entre 1593 - data da entrada dos franciscanos no Japão e início da sua missão no arquipélago - e 1594, uma vez que o memorial, segundo consta no manuscrito, foi entregue ao papa Clemente VIII em janeiro de 1595, pelo dominicano Bartolomeu Lopez. A apologia, por sua vez, encontra-se também sem especificação de data. Contudo, o último acontecimento apontado na mesma foi a liberação de Felipe III, em 1600, para que os religiosos das ordens mendicantes entrassem no Japão, desde que fossem pela rota portuguesa (pela Índia). Logo, supomos que a obra não é muito posterior a essa data.

Acerca do autor do memorial de acusação citado no manuscrito não sabemos muito e não podemos dizer com total certeza seu nome. Contudo, na Resposta ele é apontado como um capitão que estava engajado no trato da seda ${ }^{26} \mathrm{e}$ que teria passado pelo Japão em 1588. Acontece que neste ano, somente um navio mercante aportou no Japão e seu capitão era Jerônimo Pereira. A questão é que ele morreu no ano seguinte em um naufrágio, o que impossibilita que a autoria do memorial seja sua, uma vez que a missão franciscana no Japão se iniciara somente em 1593, com a embaixada de Pedro Batista. Ao investigar mais acerca dos capitães dos navios envolvidos no comércio da seda chinesa entre Macau e Japão chegamos a um outro nome: Gaspar Pinto da Rocha. Este era um mercador português que, em 1593 e 1594, foi capitão do navio que chegou a Nagasaki ${ }^{27}$ levando os quatro franciscanos que foram na embaixada das Filipinas ao Japão. Ainda que o tráfego para o arquipélago de religiosos que não fossem da Companhia de Jesus estivesse proibido, Rocha fez vista grossa (BOXER, 1988: 57-58). Além disso, é provável que ele

23 Archivo de la Real Academia de la Historia.

24 Col. Cortes, Maço 13, Tomo 1565, f. 289-300.

25 Na introdução escreve: "religiosos da nossa Companhia".

26 Na resposta ao segundo capítulo do memorial o autor afirma que o acusador era capitão da nau que ia pela seda ao Japão e se queixava do envolvimento dos jesuítas no trato da seda pelo dano particular que tinha por ver diminuído seu lucro.

27 Tal informação o cita o padre Luis Fróis SJ, em sua Historia de Japam, volume I. FROIS, Luis. Historia de Japam. Edição: Jose Wicki, Volume I, Lisboa: Biblioteca Nacional de Lisboa, 1976, p. 437. 
tenha passado pelo Japão antes disso, como cita o documento que afirma que o autor do memorial estava por lá no ano de 1588. Na obra de Afonso de Lucena, jesuíta português (1551-1623), o autor afirma que Rocha era um dos passageiros que estavam presentes no navio quando esse enfrentou um tufão e quase afundou numa travessia que faziam em direção ao arquipélago. Lucena afirma que Rocha era "bem conhecido e nomeado em Macao e Japão" (LUCENA, 1972: 76). Dadas tais evidências, cremos que seja bastante provável que ele seja o autor do memorial ao qual o documento transcrito a seguir se refere. Não se pode, entretanto, excluir a possibilidade de um outro nome.

\section{Aparato crítico}

O manuscrito transcrito abaixo encontra-se redigido em português do século XVIXVII. Joseph Schütte, ao descrevê-lo em seu catálogo, aponta as seguintes informações: sem assinatura, português, papel europeu (SCHÜTTE, 1961: 79). Na transcrição que fizemos, modernizamos a ortografia do português, ou seja, utilizamos a grafia atual dos termos como 'Majestade' para 'Magestade', 'Japão' para 'Japam' ou 'cristandade' para 'christandade', entre outros. Retiramos as consoantes duplas que não são mais utilizadas na grafia atual, como ' $n$ ' e 'l'. No caso das abreviaturas, as escrevemos por extenso. Modificamos os números utilizando os caracteres romanos (como para 'Clemente VIII') e optamos pela pontuação segundo as normas atuais. Para o caso de cidades que permanecem com o mesmo nome na atualidade modernizamos a grafia, para as outras, como 'Meaco', ou nomes de personagens históricos japoneses, mantivemos a grafia utilizada pelos jesuítas.

\section{Referências Bibliográficas}

ARNAIZ, Gregorio. Observaciones sobre la Embajada del Dominico P. Juan Cobo. Monumenta Nipponica, v. 2, n. 2 (Julho, 1939), pp. 634-637.

. The Great Ship from Amacon. Macau: Instituto Cultural de Macau, 1988.

BERNABÉ, Renata Cabral. A Construção da Missão Japonesa no Século XV. 2013. Dissertação (mestrado em história) - Faculdade de Filosofia, Letras e Ciências Humanas da Universidade de São Paulo, São Paulo.

BOXER, Ralph Charles. The Christian Century in Japan 1549-1650. Berkeley University of California Press, 1967.

CORREIA, Pedro Lage Reis. A Concepção de Missionação na Apologia de Valignano. Lisboa: Centro Científico e Cultural de Macau, 2008.

. O Triunfo do experimentalismo na missão do Japão: Alessandro Valignano (1539-1606) e a organização da embaixada japonesa à Europa em 1582. In: ANAIS DO SIMPÓSIO INTERNACIONAL NOVOS MUNDOS - NEUE WELTEN. PORTUGAL E A ÉPOCA DOS DESCOBRIMENTOS, Berlim, nov. 2006. 
ELISON, George. Deus Destroyed. The Image of Christianity in Early Modern Japan. Massachusetts: Harvard University Press, 1973.

FROIS, Luis. Historia de Japam. Edição: Jose Wicki, Volume I, Lisboa: Biblioteca Nacional de Lisboa, 1976.

GAY, Jesús Lopes. EI Catecumenado Mision Japon. Roma: Libreria dell Universita Gregoriana, 1966.

LUCENA, Afonso de. Erinnerungen aus der Christenheit Von Ômura. De Algumas Cousas que Ainda se Alembra o Pe. Afonso Lucena que Pertenciam à Christandade de Ômura [1578-1614]. Edição: Josef Franz Schütte, Tóquio: Sophia University, 1972.

MANZANO, Ainhoa Reyes. La Cruz e La Catana: relaciones entre España y Japón (Siglos XVI-XVII). 2014. Tese (doutorado) - Universidade de la Rioja, Departamento de Ciências Humanas.

MARINO, Giuseppe. Breve Apologia de Gil de la Mata: Estudio de un Inédito para Felipe II. Tzintzun · Revista De Estudios Históricos. Morelia, v. 60, jul.-dez. 2014, pp. 306-337.

PEREZ, Lorenzo. Fray Juan Pobre de Zamora: su relación sobre la pérdida del galeón "San Felipe”, y martirio de San Pedro Bautista y compañeros. Madri: R. Velasco, 1931.

. Cartas y Relaciones del Japon, Madrid: G. López del Horno, 1916.

SCHÜTTE, Josef Fraz. Documentos sobre el Japon Conservados em la Coleccion Cortes de la Real Academia de la Historia. Madri: Imprenta y Editorial Maestre, 1961.

SOLA, Emilio. Historia de un Desencuentro, España y Japón 1580-1614. Archivo de la Frontera: e-libros, 2012.

TALADRIZ, José Luis Alvarez (Ed.). Relaciones e Informaciones - Documentos Franciscanos de la Cristandad de Japón (1593-1597). Osaka, 1973.

TRONU, Carla. The Rivalry between the Society of Jesus and Mendicant Orders in Early Modern Nagasaki, Agora: Journal of International Center for Regional Studies, n. 12, 2015.

VALIGNANO, Alessandro. Sumario de las Cosas de Japón. Editor: Jorge C. Alvarez-Taladriz, Monumenta Nipponica Monographs, Tóquio: Sophia University, v. 9, 1954.

. Apología de la Compañia de Jesus de Japón y China (1598). Editor: Jorge C. AlvarezTaladriz, Osaka, 1998. 


\section{APÊNDICE}

Respostas da Companhia aos capítulos que se deram a Sua Majestade contra os padres de Japão

[f. 289r.] Diz Antônio Colaço da Companhia de Jesus e seu procurador em Corte das províncias de Portugal que à sua notícia veio um memorial que a Vossa Majestade se deu contra os religiosos da nossa Companhia que andam em Japão, no qual the são impostas algumas cousas pelas quais (tomando-se no verdadeiro sentido, e conforme a intenção e zelo com que as fizeram) mais merecem os ditos religiosos louvor que vitupério, e por serem tais o papa Clemente VIII, sendo-lhe apresentado quase este memorial em janeiro de 1595, por frade Bartolomeu Lopez da ordem de São Domingo, não somente nem [deferiu] a seu intento (o qual é que se abra a porta de Japão a todos os religiosos por todas as partes que quiserem entrar) mas confirmou de novo o breve de Gregório XIII, no qual com graves censuras proíbe a todos esta entrada, tirando aos da Companhia, pelas razões que então teve, as quais hoje perseveram na mesma força, e pelas mesmas El-rei Felipe II que está em glória, vendo os capítulos que frade João de Garrovilhas provincial de São Francisco das Filipinas enviou a esta Corte em descrédito dos nossos religiosos de Japão no mesmo ano de 1595 (que são quase os deste memorial) e ouvindo Sua Majestade as respostas que a elas lhe deu o procurador da Companhia de Japão que naquele ano viera a Madri, mandou por sua real provisão no ano de 1596 que nenhuma pessoa secular, nem eclesiástica, passasse das Filipinas ao Japão ou China, e ao Vice-rei da Índia Oriental passou outra em que lhe mandava, que se alguma pessoa secular fosse das Filipinas a Japão ou China a castigasse como lhe parecesse, e sendo eclesiástica a embarcasse nas naus da Índia para Portugal. É certo que, se tiveram fundamento os capítulos e queixas sobreditas dadas em Roma à Sua Santidade, e em Madri à Sua Majestade, que assim um como o outro deram remédio conveniente mudando o modo que na cultivação daquelas cristandades guardavam os ditos religiosos da Companhia, o que não fizeram antes dos ditos capítulos e queixas resultaram o breve, e as provisões apontadas, com que as cousas da Companhia ficaram confirmadas, e seu modo de proceder aprovado, e para que Vossa Majestade vendo as respostas da Companhia a este memorial confirme o que está mandado.

Pede ele suplicante a Vossa Majestade seja servido de as mandar ver, e ordenar o que mais convém ao aumento da cristandade daquelas partes, e ao maior serviço de Deus e bem de seus Estados porque isto é o que a Companhia mais deseja, e para maior clareza se põem as próprias palavras deste memorial com suas respostas ao pé dele.

[289v.]

\section{Capítulo primeiro do memorial}

É grande serviço de Deus virem os frades de todas as ordens a todas a partes da Índia, China e Japão pregar o santo Evangelho 


\section{Resposta}

Examinando o papa Gregório XIII se era serviço de Deus abrir a porta de Japão e China a todas as religiões enquanto os universais senhores daqueles reinos não favoreciam a cristandade ou se faziam cristãos, entendeu que convinha cercar-se, e assim o mandou com graves censuras em um motu próprio no ano de 1585, e fazendo vários religiosos grandes instâncias ao papa Clemente VIII para que revogasse o dito breve, ouvindo-os por alguns anos, o confirmou por outro no ano de 1595, posto que depois, à instância de Vossa Majestade, concedeu ano de 1600, que pudessem ir os mendicantes pela Índia Oriental somente e El-rei Felipe II, que está em glória, ouvindo no ano de 1595 as queixas de vários religiosos mandou fechar ${ }^{28}$ a dita porta por suas reais provisões dadas no ano de 1596, as quais se assentaram nos livros da Câmara da cidade de Goa, e nas da cidade de Manila, e os bispos de Japão sempre escreveram à Vossa Majestade que isto era o que mais convinha ao bem daquela igreja, o que também escrevem o arcebispo de Goa, os vice-reis da Índia, e todos os que tratam desta matéria sem paixão afirmam não ser ainda tempo para esta porta se abrir, e que será grande serviço de Deus não entrarem outros religiosos em Japão e China enquanto as coisas daquelas partes não tiverem outro termo, e há muitas razões e mui eficazes para isto, e a experiência, que é bastante prova, o tem mostrado, porque as vezes que entraram outros religiosos em Japão puseram aquela igreja a grande risco de se perder como é notório a todos, assim porque não usaram do resguardo necessário naquelas partes aonde o senhor é tirano, não quer que preguem nossa lei a seus vassalos, como por se não unirem nas opiniões e doutrina com os da Companhia que há tantos anos tratam aquelas gentes, e nos princípios das conversões importa tanto que os pregadores sejam conformes em tudo que mandado o papa Inocêncio III vários religiosos a pregar o Evangelho a Livonia logo no princípio de sua congregação para evitar a diversidade nas opiniões e modo de proceder, ordenou que todos se vestissem do mesmo hábito: «Ne si dispar in vobis obsertantia fuerit, et dissimilis habitus, apud eos, qui unum Evangelium praedicatis, scandalum suscitetur» - diz o papa no capitulo - Deus qui de vita, et honestate cleric, e se esta razão foi bastante em Livonia muito mais em Japão aonde a diversidade de muitas seitas que seguem os japoneses, lhes é muita causa de sua perdição, e a união que conhecem em nossa santa lei é argumento notável do conhecimento dela. E sendo este negócio tratado por tais pessoas como as acima referidas, e ponderadas as razões que há na matéria, tomaram a sobredita resolução, e as entradas que vários religiosos naquelas partes fizeram, a confirmaram por boa, claro está que não somente é serviço de Deus irem frades a Japão (como diz o autor deste memorial) enquanto o senhor dele não favorecer a pregação do Evangelho, antes em matéria de muito escrúpulo conceder-se esta entrada pelo evidente perigo em que se põe aquela igreja como outras vezes temos experimentado

[290r.]

28 No manuscrito çerrar. 


\section{Memorial}

Porque sou testemunha que foram a Japão frades menores de São Francisco e faziam lá muito na conversão vendo os japoneses sua pobreza que concordava com o que eles lhe pregavam e que eram pobres

\section{Resposta}

Mal podia ser testemunha do fruto que os frades faziam em Japão se esteve lá no ano de 88 como neste memorial diz abaixo no capítulo segundo, porque a primeira vez que frades menores entraram em Japão foi no ano de 1593, como eles e todos confessam, e consta das cartas que o bispo daquelas partes escreveu a Vossa Majestade, e do ano de 88 até o de 93 vão cinco anos, mal podia logo ver o fruto que na conversão faziam em Japão os que por ventura nem estavam nas Filipinas donde partiram, e se o direito diz: «qui semel mentibus est semper praesumitur esse». Bem se pode ver o crédito que merece o autor deste memorial. E dado que pudesse ser testemunha por estar com os frades menores em Japão não pode afirmar que converteram mais que os da Companhia, porque no primeiro artigo de um processo tirado em Japão no ano de 92 por autoridade de justiça, se prova com várias testemunhas que os da Companhia foram os primeiros pregadores do Evangelho em Japão e do ano de 49, em que entraram, até o de 87, em que Cambacudono os começou a perseguir, não tendo outros companheiros, fundaram ali 240 igrejas e batizaram mais de 250 mil almas e fizeram dois seminários nos quais se criavam em letras e bons costumes mais de 200 mancebos nobres e batizaram a alguns reis e senhores japoneses. E no mesmo ano de 87, que foi o de seu desterro, andando escondidos, converteram mais de cinquenta mil, não falando das crianças que batizaram, e da mesma maneira foram sempre continuando, como consta das cartas escritas a nosso Geral. E no quarto e nono artigo do segundo processo dos três que em Japão se fizeram sobre estas matérias, se prova por testemunhas que levando os frades menores a carta do governador das Filipinas a Cambacudono lhes falou soberbamente contra o dito governador que os mandava ameaçando com seu exército se logo lhe não dava a obediência, e a eles disse que logo se tornassem para suas terras porque não queria que pregassem sua lei contra a dos seus pagodes, mas pedindo-lhe eles licença para ficarem até o ano seguinte o governador responder a sua, e para irem ao Meaco a ver suas grandezas que pudessem contar aos seus, ainda que no princípio lhe a negou, depois a concedeu, e estando no Meaco se recolheram em casa de Faxegaba, gentio criado de Cambacudono, o qual lhes mandou que não pregassem nossa Santa lei, e eles o prometeram, e por estarem mal acomodados, lhe pediram sítio, em maio de 94 , em que pudessem edificar igreja e casa própria, o que Cambacudono concedeu por meio do governador do Meaco com condição que não pregassem nem houvesse em sua casa concurso de cristãos, e não cumprindo o que prometeram foram ameaçados e depois crucificados no ano de 95, e se estes religiosos desta maneira foram recebidos em Japão de Cambacudono, e com tanta cautela the foi dada licença para edificar nele proibindose-lhe a pregação do Evangelho, e trato como a gente que haviam [f.290v.] de converter, 
e tão pouco tempo estiveram naquelas partes sem poderem discorrer por elas, como é possível que fizessem lá muita conversão?

\section{Memorial}

Que eram pobres e não mercadejavam, nem tinham tratos alguns, e concordavam nesta pobreza com os seus bonzos, o que era parte de se converterem muitos, e seguirem a lei Evangélica, as quais partes eles não viam nos da Companhia

\section{Resposta}

Três coisas nota nestas palavras. A primeira que os da Companhia são ricos em Japão. A segunda que são mercadores. A terceira que na pobreza concordavam os frades com os bonzos. Quanto a primeira o certo é que a Companhia sustenta em Japão mais de 800 pessoas e ainda que nem todos são religiosos andam todavia todos ocupados na cultivação daquela cristandade, e tem muitas igrejas que [paramentam] provendoas de todo o necessário, e sustentam muitos moços nobres que em alguns seminários aprendem e se fazem clérigos, fazem também muitas missões a diferentes reinos de Japão em que gastam muito apresentando peças aos senhores gentios para os terem benévolos e amigos e assim poderem melhor proceder em seus ministérios, e para todos estes gastos não têm mais que a esmola que sua Santidade dá cada ano nesta Corte de quatro mil escudos e dois mil cruzados que Vossa Majestade lhe dá na Índia, e os de sua Santidade muitas vezes se perdem, perdendo-se as naus, e os de Vossa Majestade muitos anos se não pagam por culpa dos oficiais que têm por perdido o que se dá para semelhantes obras, e o mais se tira de esmolas assim de portugueses como de senhores japoneses já convertidos quando as contínuas guerras que há entre eles lhe dá lugar para o poderem fazer, e esta é toda a riqueza que os da Companhia têm em Japão, nem se achará outra tirando a esmola que os mercadores de $\mathrm{Meaco}^{29}$ lhes dão a conta da seda de que abaixo se dará razão.

Quanto a segunda coisa, que nota de serem mercadores, se responderá satisfazendose ao que diz no capítulo segundo deste memorial.

Quanto a terceira nota, que os frades concordam na pobreza com os bonzos de Japão, é certo que estes bonzos são riquíssimos não somente nos mosteiros, que têm de muitos mil cruzados, mas também em suas pessoas particulares, ajuntando com sua cobiça muito dinheiro, e tal houve ao qual em sua morte acharam mais de cem mil cruzados em dinheiro, e se isto é ser pobres quem se poderá chamar rico? Nem se pode bem inferir que a pobreza nos ministros do Evangelho naquelas partes é causa de maior conversão porque é grande motivo aos gentios verem em suas terras homens que de tão longe os vão buscar não pretendendo nem aceitando deles ouro ou prata mas somente procurando o bem de suas almas ensinando-lhes o caminho da salvação, o que não

29 Na cópia manuscrita sucessiva, quase idêntica, a cidade apontada é Macau, o que é mais apropriado considerando a rota das naus mercantes portuguesas. Cf. Real Academia de la Historia, seção «Cortes», tomo 2665 , f. $296 \mathrm{v}$. 
podem fazer tão livremente os que por sua muita pobreza houverem de esperar deles a sustentação, e os mais gastos ordinários, e os da Companhia buscam entre os portugueses o necessário para seus gastos por não o pedirem aos gentios e cristão ordinários aos quais muitas vezes acodem [f. 291r.] os mesmo religiosos com suas esmolas.

\section{Capítulo segundo do Memorial}

$\mathrm{Na}$ China e Macau empregam os padres da Companhia quantidade de dinheiro todos os anos em seda crua que levam na nau para Japão passante de cem quintaes de seda todos os anos, e a levam sem fretes nenhuns que é em prejuízo do povo, do bem comum, e do capitão da nau, e a vendem no Japão como fazem quaisquer outros mercadores as suas, de que se escandalizam os japoneses

\section{Resposta}

Contando-se o que nesta matéria passa na verdade se verá quão enganado vai o autor deste memorial, o qual já que foi por capitão desta nau, e se queixa pelo dano particular que recebeu de não levar direitos desta seda, poderá se informar melhor do caso o qual é o seguinte. Em Macau, houve um mercador português por nome Luís d'Almeida, o qual vendo o grande fruto que os da Companhia faziam em Japão com o pouco que tinham para acudir às suas obrigações. Sempre os ajudou com esmolas, e entrando por tempos na Companhia deixou-lhes em Macau quatro mil cruzados com condição que andassem sempre vivos no trato da seda da China para Japão dando-se o ganho deles aos que andavam em Japão para suas necessidades, por entender que o de Europa lhes faltaria muitas vezes. Correu sempre este negócio pelos mercadores de Macau não se metendo os da Companhia em mais que em receber deles o que se tirava do principal daquela seda, e todavia desejavam haver outro modo de menos inconvenientes, e por esta causa o nosso Geral encomendou muito ao Visitador Alexandro Valignano que mandava aquelas partes que o buscasse com cuidado, e chegando ele a Macau no ano de 78 se informou particularmente do caso e achando que se tirava esta esmola a Japão punha em grande perigo aos que andavam nele pregando, tratou com a cidade de Macau do remédio que se podia dar, e assentaram que a mesma cidade tomasse a sua conta estes quatro mil cruzados como seus, e nos mil e seiscentos picos de seda que o seu feitor cada ano leva a Japão, entrassem cinquenta, e o ganho deles conforme ao primeiro preço porque fossem vendidos se desse aos da Companhia que estavam em Japão ainda que se não vendesse toda a seda que levava, e de tudo fizeram um instrumento público firmado por todos, e tirasse deste cinquenta picos de seda como mil e seiscentos cruzados de ganho. Confirmou este assento em Goa o vice-rei Dom Francisco Mascarenhas Conde de Santa Cruz a 18 de abril de 1584 e a 29 de abril de 1589 se tornou a confirmar pela mesma cidade de Macau. E porque aqueles religiosos ainda tinham dúvidas neste negócio, escreveram ao nosso Geral para que o tornasse a ver, e ele o tratou com o papa Gregório XIII, o qual não somente confirmou por visto e lícito, mas disse que isto não se podia 
chamar propriamente trato, pois se fazia por pura necessidade, e na verdade parece que milita neste caso aquele axioma: «quod pro charitate introductum est non debet contra charitatem militare», o qual fora se por falta do necessário se houvera de largar tal empresa como a de Japão. Esta é a verdade pontualmente, donde se vê que este trato na forma sobredita o tem aqueles religiosos com beneplácito, e pela mão daquela cidade confirmado pelo vice-rei da Índia em nome de Vossa Majestade, e aprovado pelo Sumo Pontífice a com parecer de nosso Geral e seus assistentes, e assim não se pode por esta causa afirmar que os da Companhia de Japão e China mercadejam, sendo esta a ocasião porque o dizem, nem havendo outra alguma, e correndo este modo de trato somente [f. 291v.] pelos mercadores de Macau, sem nele entrar pessoa alguma da Companhia mais que em cobrar deles a dita esmola.

\section{Memorial}

E assim o mesmo rei de Japão no ano de 88 por esta causa, e por terem artilharia os lançou fora de Japão, e lhes mandou derrubar as suas igrejas estando eu lá presente a isto no mesmo ano de 88 .

\section{Resposta}

Como pode ser que Cambacudono, rei de Japão, desterrasse dele aos da Companhia pelo trato da seda que tinham feito com os mercadores de Macau que não eram de sua jurisdição e porque havia ele de querer castigar aos que andavam em seus reinos pelos danos que recebia o povo de Macau deste trato como neste capítulo aponta este autor? Pelo que não deve ser a causa do desterro dos da Companhia e da destruição das igrejas a que infere neste capítulo, e melhor lhe fora não confessar que em sua presença se fez tal afronta a nossa santa lei e a seus ministros ainda que não pode assistir a ela porque, como aqui confessa, esteve em Japão no ano de 1588, e as igrejas foram destruídas, e os da Companhia desterrados no ano atrás de 1587, como consta do quinto artigo do primeiro processo que se tirou por testemunhas no ano de 1592. E quanto à causa desta destruição e desterro, não foi outra que a pregação do Evangelho contrária aos pagodes, como afirma Genofoim ${ }^{30}$, governador do Meaco, na que escreveu ao Vice-provincial da Companhia, no ano de 1593, dizendo-lhe que escrevera ao embaixador da Índia que nem os da Companhia nem a lei que pregavam tiveram culpa desta perseguição, mas somente o haverem pregado contra a lei dos seus pagodes e que assim se declarava no edito que Cambacudono fizeram contra eles, e o mesmo Cambacudono o tinha dito ao Irmão João [Rois] diante de muita gente, e a ocasião que este tirano teve para mandar naquele tempo executar este perseguição foi por lhe impedirem os da Companhia certas donzelas cristãs e nobres de que queria usar mal, e sendo esta a verdadeira causa desta destruição das igrejas e desterro destes religiosos, provada com tantas testemunhas, e pelos mesmo que a mandaram e executaram, não há para que inventar outra.

30 Na cópia do manuscrito lê-se 'Guenifoim'. 


\section{Capítulo terceiro do Memorial}

Os padres da Companhia tinham no Japão no ano de 88 armazém de artilharia grossa de bronze, e arcabuzes, e servindo eu de capitão da nau de Japão no ano de 88 da perseguição de Cambaco, rei de Japão, eles meteram dentro da dita nau muitas peças de artilharia por lhe estar nela segura de Cambaco the a tomar quando lhe derrubou as igrejas que vi derrubar parte delas, e as cruzes.

\section{Resposta}

Se este capitão informara bem que artilharia era esta, achara que não podia ser da Companhia nem ela tal teve nunca, e soubera facilmente por seu notório a todos que Elrei dom Bartolomeu, senhor do porto de Nagasaki, vendo como a nau dos portugueses que vai cada ano a Japão não tinha porto seguro em que desembarcasse, e que por essa causa não ousavam eles de vir com suas mercadorias, por não perder o proveito que the vinha destas vindas, deu aos da Companhia não a cidade, nem sua renda ou jurisdição, senão o porto, para que entendendo os portugueses que era dos da Companhia viessem a ela seguramente, mas deste porto não tinham renda alguma posto que os portugueses sempre lhes davam esmolas com as quais fizeram ali casa e igreja das melhores de Japão, e os portugueses, [f.292r.] para estarem mais seguros e guardarem melhor suas fazendas, puseram neste porto alguns tiros de artilharia que o vulgo cuidava ser dos padres da Companhia, e quando Cambacudono, no ano de 1587, os desterrou e lhes derrubou suas igrejas, tomou este porto para si, com tudo o que nele havia. E por ventura que esta ocasião procurassem os ditos religiosos recolher a nau a artilharia que pudessem por fazerem aquele bem aos portugueses dos quais recebia tantas esmolas se é verdade que a meteram na nau, e se a meteram mais é para louvar que para culpar. Nem houve em Japão outra alguma artilharia de que se pudesse tomar ocasião para se dizerem semelhantes coisas dos da Companhia, nem eles usam de semelhantes armas no ministério da conversão, de livros espirituais, de medalhas, relíquias, contas bentas e de rosários [sim] por serem armas mais a propósito para seu intento.

\section{Memorial}

E lhes disse o mesmo Cambacu que a sua lei deles não era boa, pois lhe consentia o trato da mercancia, e o que os seus bonzos que se mantinham de esmolas, não faziam, e que logo sob pena das mortes se saíssem fora de seu reino, o que eles logo fizeram indose fora de Facata onde o rei estava, e tomando hábito de leigos que chamam quimonos ${ }^{31}$ se esconderam pelas aldeias dos cristãos querendo antes ser confessores que mártires.

\section{Resposta}

Primeiramente nota aos da Companhia de mercadores, ao que se tem respondido. Alega com a pobreza dos bonzos, e já se tem mostrado quão pobres

31 No texto: 'quimões'. 
são. Dá a causa do desterro dos da Companhia, e temos provado não ser esta. Finalmente vitupera mudarem os da Companhia o hábito neste desterro, e esconderem-se pelas aldeias dos cristãos e a esta última queixa se responde que mudar o hábito e esconder-se quando o tempo o pede é coisa mui usada na igreja de Deus, e que Cristo nosso Senhor ensinou por palavras e exemplo, e seus Apóstolos e muitos santos canonizados fizeram, e hoje o fazem os da Companhia em Inglaterra, conservando e aumentando os católicos em hábito de soldados com suas espadas na cinta, mas de tal maneira que sendo necessário dão as vidas por confissão da fé católica. E este modo de proceder não somente não é notado dos sumos pontífices, reis e senhores do mundo, mas mui louvado e aprovado de todos, e por esta causa Vossa Majestade sustenta, favorece e conserva os seminários de Espanha para esta obra ir adiante, e dela se recolher o fruto que vemos cada dia. Pelo que, se os da Companhia em Japão mudaram o hábito e se esconderam pelas aldeias dos cristãos, não foi por medo da morte nem de Cambacudono, mas para melhor poderem acudir aos mesmos cristãos, conservando-os na fé que receberam, consolando-os com sua doutrina, animando-os para os trabalhos que temiam e convertendo aos que de novo aqui o quisessem fazer. E demais destes proveitos, que de seu retiramento se seguiram, houve outros de muita importância, a saber, não porem a perigo os senhores cristãos, os quais se em público favoreceram aos ministros do Evangelho sem dúvida se perderiam com Cambacudono que os tinha ameaçado, e se os frades fizeram o mesmo não sucedera a grande tormenta de Cambacudono contra eles e contra nossa santa fé que totalmente pretendeu desterrar de Japão. E como deste retiramento que os da Companhia fizeram se seguiram tantos proveitos naquela igreja não se deve notar por culpa antes por muita prudência, e assim eles o tem por grande glória sua. E quanto ao hábito não era indecente, [f.293v.] porque eram umas largas como em Japão costumam trazer os letrados e os seus religiosos, nem era tal que por ele deixassem de ser conhecidos dos cristãos, e com isto mostraram a Cambacudono que em tudo lhe obedeciam, como não fosse contra nossa santa fé. Assim que foi melhor esconderem estes religiosos naquela ocasião, ser confessores que mártires, guardando a ocasião do martírio para outro tempo em que se visse maior glória de Deus e bem de suas almas e da cristandade daqueles reinos.

\section{Capítulo quarto do memorial}

Os padres da Companhia tinham em Japão uma grande fusta de feição de gale em que andam dumas ilhas para outras a seus negócios bem artilhada com gente, e um padre por capitão dela, ao qual a chamam o capitão da fusta.

\section{Resposta}

É verdade que naquele tempo um religioso que tinha a seu cargo visitar as casas e igrejas em que os da Companhia estavam, teve uma embarcação em que andavam por não depender de barqueiros gentios e poder com maior brevidade acudir 
a todos, visitando-os e acudindo-lhes com o necessário para melhor continuarem na pregação do Evangelho. E estes, e não outros, eram os negócios que andavam nesta embarcação a que chama fusta, e porque o mar de Japão anda sempre cheio de corsários que não perdoam a vida nem a fazendo dos passageiros, bem é de crer que este religioso levaria gente consigo e algumas armas para se defenderem, e porque ele era a principal pessoa que ia nesta embarcação, lhe chamariam o capitão dela, e posto que a necessidade e o desejo de melhor acudir aos seus foi causa de a fazer, contudo, nosso geral sabendo dela, a mandou desfazer, e assim não há que reparar nesta matéria.

\section{Capítulo quinto do memorial}

Em Japão, por ordem dos padres da Companhia, casam gentios com cristãos e cristãos com gentias e os filhos que deles nascem a metade são cristãos e a metade são gentios, porque o pai cristão faz a sua parte e a mãe gentia faz os seus gentios.

\section{Resposta}

Quanto neste particular, os da Companhia fazem em Japão o tem consultado com o seu Geral e ele com as vontades de Europa e comunicado com os sumos pontífices, por cuja ordem e direção fazem tudo, e há privilégio para que possam coabitar os cristãos com gentios, porque moralmente é certo que o cristão há de ganhar o gentio para Cristo. Nem a repartição dos filhos se faz na forma que este capitão refere, ao qual não compete saber nesta matéria tanto com os ditos religiosos, por serem letrados e mais versados nestas coisas que quem se ocupa em armas como capitão e soldado.

\section{Capítulo sexto do memorial}

No Japão, passando os padres da Companhia pelas ruas, os japoneses se the baqueiam e deitam por terra, assim príncipes como todos os demais, fazendo-lhes grandes cortesias que eles consentem se lhes façam, foi também a causa de os lançar fora de seu reino.

\section{Resposta}

Primeiramente a cortesia que os japoneses fazem como também os chineses, e baqueando-se uns aos outros, [f.293r.] como em Europa tirando-se os sombreiros, e que o faça aqueles novos cristãos aos ministros do Evangelho que é? Antes muito para estimar e agradecer, e não somente é certo que lhe a fazem os cristãos, mas também muitos gentios, pela estima que deles fazem. E indo o beato padre Francisco Xavier visitar a El-rei de Bungo, sendo gentio, lhe fez o rei aquela mesma reverência, baqueando-se-lhe todo, e, todavia, não se pode notar em tão santo varão haver consentido nela. E se esta reverência aos sacerdotes e ministros da igreja houver sempre, não veremos os danos por nossa causa que por falta dela se tem 
visto nas províncias do norte. É certo que não somente os japoneses fazem naquelas partes aos da Companhia a tanta reverência, mas também a fazem os portugueses que lá vão, os quais acompanham aos ditos religiosos muitas vezes quando vão visitar a alguns governadores ou senhores gentios, ensinando-os por exemplo a cortesia que os cristãos têm aos seus sacerdotes e pregadores, e sabemos que os descobridores das Índias, para mostrarem aos novamente convertidos o respeito que havia de ter aos ministros da igreja e pregadores do Evangelho e a reverência com que os havia de tratar, falavam de joelhos aos sacerdotes e religiosos, e assim não há para que dar em culpa aos da Companhia esta reverência que os japoneses lhe fazem, nem menos [dizer-se] que por esta causa foram lançados de Japão. Por ventura quererá dizer que Cambacudono, vendo a reverência que todos lhe tinham, temeu que lhe tomassem o reino. Mas como é de crer que um rei tão poderoso, que em tão breve tempo se fez universal senhor de todos aqueles reinos, e que por sua soberba cuidava que todos se lhe haviam de sujeitar, temesse a quatro religiosos estrangeiros que andavam em suas terras ocupados somente na pregação e promulgação da lei de Deus?

\section{Capítulo sétimo do memorial}

Soube em Japão de verdadeira certeza que os japoneses que foram a Roma e vieram a Espanha no ano de 82 foram filhos de mercadores homens honrados, e não serem filhos de reis como cá os intitulavam, e quando eles de cá foram, eu os encontrei na China vindo eu de Japão, e o padre Mesquita que veio com eles, e os tornou lá levar, me disse a mim que lhes fizesse grandes cortesias porque o santo padre e Sua Majestade lhe as fizera com grandes mercês.

\section{Resposta}

Não sei como pode dizer que soube de verdadeira certeza que os japoneses que vieram a Roma eram filhos de mercadores, porque em Japão, onde ele disse que o soube, era bem notório que Ito dom Mâncio era neto de E- rei de Fiunga, filho de uma sua filha e de um senhor primo do mesmo rei e da mesma família e casa de Ito, e por essa causa se chamava Ito dom Mâncio, e querendo El-rei Francisco de Bungo mandar dom Jerônimo, sobrinho seu, por estar ausente nas partes do Meaco e não poder vir a tempo mandou em seu nome a dom Mâncio, primo do dito dom Jerônimo, e este era primo dos quatro japoneses. O segundo se chamava Chinguio dom Migual, primo irmão de dom Protasio, rei de Arima, e sobrinho de dom Bartolomeu, senhor de Vomura, o que tudo consta do livro que fez o padre Duarte de Sande da vinda destes príncipes, impresso em Macau no ano de 1590, e somente estes dois trouxeram título de Embaixadores, e vieram por seus companheiros dom Martinho e dom Julião. E para se saber quem eles eram, bastava saber-se a nobreza dos dois embaixadores que os escolheram para companheiros de tal jornada, mas para que [f.294v.] se entenda se eram filhos de mercadores, dom Martinho tinha casada sua irmã com o irmão do mesmo senhor de Vomura, e seu irmão menor 
era senhor de uma fortaleza das melhores das terras de Omura em que tinha muitos vassalos, e era dos principais parentes do mesmo senhor de Omura, e dom Julião era filho de um senhor que tinha sua fortaleza nos confins das terras de Firando e de Omura, donde se pode ver se era muita razão que fossem reverenciados e estimados por sua nobreza, e principalmente por serem as primícias que vinham de partes tão remotas dar obediência à Igreja romana em nome de tão católicos reis, como foram dom Francisco rei de Bungo e com Protasio, rei de Arima, e quando os sumos pontífices, cabeças da igreja, e el-Rei Felipe rei das Espanhas os estimaram tanto e honraram, não eram muito o capitão da nau de Japão lhe fizesse ou mesmo pelos mesmos respeitos.

\section{Capítulo oitavo do memorial}

Os padres da Companhia na Índia são ricos e têm rendas e aldeias que rendem para eles e bem podem escusar o trato da mercancia na China e Japão, antes não usando dela farão muito mais fruto na conversão das almas, e serão menos escandalosos e segundo minha sentença me parece serviço de Deus privá-los da mercancia, e deixarem ir os padres franciscanos ao Japão onde os desejam e aos demais das mais religiões.

\section{Resposta}

Quando as rendas da Companhia na Índia foram tantas, como neste capítulo aponta, e não tão tênues que escassamente bastam para os gastos ordinários que se fazem naquelas partes no sustento das casas, e religiosos que ali traz a Companhia ocupados na conversão da gentilidade, não inferia bem que para se tirar o trato da China bastava serem ricos os da Índia, porque a renda de uma província não se pode gastar com outra como nem a de um Colégio com outro, ainda que seria da mesma província, e o trato da China não é causa de haver menos conversão, como a experiência até agora tem mostrado, nem menos é causa de escândalo aos que andam naquelas partes, porque os mesmo portugueses de Macau, a quem mais tocava escandalizar-se deste trato, são os que o negociam e têm a sua conta. É bem verdade que a Companhia deseja muito que haja outro remédio para aqueles religiosos se poderem conservar, e se Vossa Majestade quisesse fazer mercê à Companhia de dar esta seda à cidade de Macau e oferecer-lhe alguns privilégios com que eles dessem aqueles religiosos em Japão com que pudessem sustentar, ou parte de doze mil cruzados que gastam cada ano e Vossa Majestade outra parte, a Companhia a aceitaria como mercê mui particular, porque por esta via se poderá conservar aquela cristandade tão grande e tão honrada e se livrará a Companhia de semelhantes queixas, e não haverá quem desta se escandalize, ainda que sem fundamento, porque em tudo pretendem acertar para maior glória e honra de Deus nosso Senhor, por cujo amor se desterram de suas terras para tão remotas aonde tanto se padece.

Nos últimos capítulos refere as pessoas que podem ser perguntadas destas coisas, e muitas delas estiveram na Índia muito depois que passaram as coisa de aqui se queixa, 
e entre os que [f.300r.] $]^{32}$ nomeia dos antigos poderá referir o conde de Santa Cruz que era Vice rei no tempo que se assentou o que toca do trato da China e a Fernão Teles de Menezes que foi governador da Índia e mui versado nas coisas daquelas partes e a outros dos mais antigos e que poderão testificar daqueles tempos, e todos sem dúvida dirão o muito que a Companhia serve a Deus e a Vossa Majestade em todas as partes de suas conquistas e juntamente a importância, assim para o bem da conversão como para a conservação de seus estados, de que a porta de Japão e China se cerre principalmente pelas Índias ocidentais também pelas orientais enquanto não houver um senhor universal daquelas partes que favoreça muito a conversão e enquanto o não houver parecer que se deve deixar a Companhia que proceda como até agora, pois se tem visto que com este modo que guardam têm ganhado tantas almas para Deus.

32 A última página do manuscrito está localizada, na organização do arquivo, apenas após a cópia do mesmo. Daí a razão pela qual pula-se cinco fólios. A numeração apontada aqui segue, portanto, correta. 